\title{
A Child with Severe COVID-19 Complicated with Onychomadesis
}

\section{Onikomadesis ile Komplike Olan Şiddetli COVID-19'u Olan Bir Hasta}

Azize PInar METBULUT'1 , Ayse METIN¹, Selma ALIM AYDIN¹, Belgin GULHAN², Aslınur OZKAYA PARLAKAY²

${ }^{1}$ Division of Pediatric Allergy and Immunology, Ankara City Hospital, Ankara, Turkey

${ }^{2}$ Division of Pediatric Infectious Diseases, Ankara City Hospital, Ankara, Turkey

\begin{abstract}
The most common symptoms of COVID-19 infection are fever and cough; but may cause respiratory, enteric, hepatic, nephrotic, neurological, and skin involvement. Onychomadesis is the proximal separation of the nail plate from the nail matrix due to a temporary cessation of nail growth. Numerous studies about cutaneous manifestations of COVID-19 were reported; however findings of nails were limited. This paper reported a case of onychomadesis which appeared on the nails after a severe COVID-19 infection (MIS-C).
\end{abstract}

Key Words: Child, COVID-19, Onychomadesis

Öz

COViD-19 enfeksiyonunun en yaygın semptomları ateș ve öksürüktür; ancak solunum, enterik, hepatik, nefrotik, nörolojik ve cilt tutulumuna neden olabilir. Onikomadesis, tırnak büyümesinin geçici olarak durması nedeniyle tırnak plağının tırnak matriksinden proksimal ayrılmasıdır. COViD-19'un kutanöz belirtileri ile ilgili çok sayıda çalışma bildirilmiş olup tırnak bulgularını içeren yayınlar sınırıdır. Bu makalede, șiddetli bir COViD-19 enfeksiyonu (MIS-C) sonrasında tırnaklarda ortaya çıkan bir onikomadesis vakası bildirilmektedir.

Anahtar Kelimeler: Çocuk, COViD-19, Onikomadezis

\section{INTRODUCTION}

Corona virus disease 2019 (COVID-19) uses angiotensin converting enzyme 2 to infect cells leading to a strong inflammatory response, however several studies demonstrated that COVID-19 in children is a relatively mild disease. Patients with a mild clinical presentation may not initially require hospitalization, but clinical signs and symptoms may worsen with progression to lower respiratory tract disease in the following weeks of illness. Symptoms which may indicate COVID-19 are fever, cough, shortness of breath, fatique, muscle or body aches, headache, loss of taste or smell, sore throat, runny nose, nausea, vomitting or diarrhea.
Recent studies have begun to lighten some of the differences in the innate and specific immune responses to coronavirus (SARS-CoV-2) in patients with different degrees of disease severity. These studies have attributed the severe form of COVID-19 to a dysfunctional innate immune response, such as delayed or deficient type I interferon responses. Neutralizing antibody responses (IgG or $\lg A$ ) have been described in severe disease which may be the cause of antibody-dependent recurrence of COVID-19 symptoms. After entry to type 2 alveolar cells, rapid viral replication and considerable epithelial and endothelial cell apoptosis occurs which lead to release of proinflammatory cytokines and chemokines such as interleukin-1 $1 \beta(\mathrm{IL}-1 \beta), \mathrm{IL}-6$, interferon-g (IFN-g) and anti-viral IFNs (IFNa and $\beta$ ). These cytokines
0000-0001-8823-5960 : METBULUT AP 0000-0002-0731-5799: METIN A 0000-0002-0102-0711: ALIM AYDIN S 0000-0003-0839-1301: GULHAN B 0000-0001-5691-2461: OZKAYA PARLAKAY A
Conflict of Interest /Çıkar Çatışması: On behalf of all authors, the corresponding author states that there is no conflict of interest. Financial Disclosure / Finansal Destek: The authors declared that this case has received no financial support. Confirmation / Onay: The written consent was received from the patient who was presented in this study.

How to cite / Atıf Yazım Şekli : Metbulut AP, Metin A, Alım Aydın S, Gulhan B, Ozkaya Parlakay A. A Child with Severe COVID-19 Complicated with Onychomadesis. Turkish J Pediatr Dis 2022;16:242-245.
Correspondence Address / Yazıșma Adresi :
Received / Geliş tarihi : 03.04.2021 Accepted / Kabul Tarihi : 01.06.2021

Online published 16.11.2021

Elektronik yayın tarihi

DOI: 10.12956/tchd.904814 
attract immune cells ( $T$ lymphocytes and monocytes) from the circulation into the infected lungs. This may explain the lymphopenia observed in $80 \%$ of patients with COVID-19. This cytokine storm also triggers NETosis (Neutrophil Extracellular Traps) which is a "regulated neutrophil death process" in which neutrophils release their nuclear chromatin and antimicrobial proteins in their granules upon stimulation. NETosis can become overactivated in severe viral and some acute/ chronic inflammatory diseases. Platelets help NET-mediated vascular damage, hypercoagulability and thrombosis leading to disseminated microthrombi and multiorgan failure. Increased NET formation has been found in autopsies of COVID-19 related ARDS (1).

Multisystem Inflammatory Syndrome in Children (MIS-C) is currently considered a rare post COVID-19 complication related with a cytokine storm whose symptoms are largely overlapping with Kawasaki disease and toxic shock syndrome (2).

In this paper, we describe our COVID-19 patient who developed MIS-C and complicated with onychomadesis in all fingernails which is seen in some systemic viral infections with high viral load.

\section{CASE REPORT}

A 12 year old boy was admitted to our Pediatric Immunology outpatient clinic with a complaint of nail dystrophy that is compatible with onychomadesis affecting 20 nails of both hands and feet in January 2021(Figure 1). Nearly 2 month before the onset of onychomadesis, he was COVID-19 positive and hospitalized for 2 weeks in our hospital (October 2020). In his medical history, he was being followed with an undefined immunodeficiency by our immunology department since 1-year of age. At 1 years of age after Measles, Mumps, Rubella (MRR) vaccination, he developed aseptic meningitis and Kawasaki disease. During the H1N1 pandemics, he developed severe

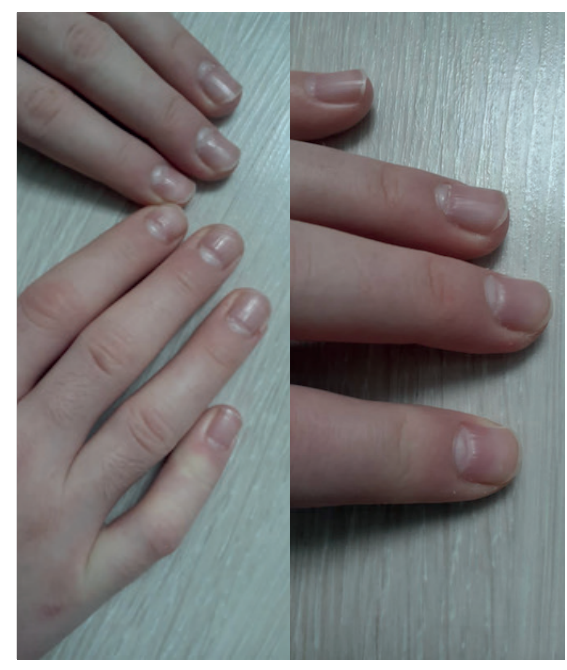

Figure 1: Onychomadesis at the both hands. pneumonia, and after that he had recurrent severe pneumonias requiring hospitalization every year. Bronchiectasis and also opportunistic infections such as CMV, fungal infections, and tuberculosis have not been detected in our patient to date. His immunological evaluation revealed normal serum immunoglobulin A (IgA), IgM, IgG, and IgE concentrations, and specific antibody titers to vaccines. In the flow cytometric test, percentages of total $\mathrm{T}$ and $\mathrm{B}$ lymphocytes, total hemolytic complement activity $(\mathrm{CH} 50)$, and nitroblue-tetrazolium slide test (NBT) for neutrophil killing were also normal. He had been followed with intravenous prophylactic immune globulin treatment for two years following a severe viral pneumonia in his preschool years with the suspicion of innate immune defect and terminated due to his good condition.

Two months before his outpatient, he was brought to our hospital's Emergency department with a complaint of $>38^{\circ} \mathrm{C}$ fever lasting for 6 days, cough for 3 days, loss of appetite, and bilateral conjunctivitis two months before this admission. His vital signs were stabil except having fever and tachycardia. The patient had no dyspnea at the time of hospitalization, respiratory sounds were diminished, bilateral multiple cervical lymphadenopathies was palpable and other systemic examinations were normal. Reverse transcription-polymerase chain reaction (RT- PCR) for COVID-19 was positive. Laboratory results at the admission were as follows: hemoglobin: 13.5 g/dL; white blood cell (WBC) count 5.4×109/L; absolute neutrophil count 3.5× 109/L; absolute lymphocytes count $1.1 \times$ 109/L and platelet: $228 \times 109 / L$. The inflammatory parameters were elevated; C-Reactive protein: $0.14 \mathrm{~g} / \mathrm{L}$ (N:0-0.005 g/L), erythrocyte sedimentation rate:32 mm/hour, interleukin-6 (IL6): $20.2 \mathrm{pg} / \mathrm{ml}$ (N:0-3.4 pg/ml), ferritin:1002 mg/L (N:7-140 $\mathrm{mg} / \mathrm{L})$. The biochemistry results were normal except follows: serum glucose (140 mg/dL) and alanine aminotransferase (ALT) (51 IU/L). Coagulation parameters were as follows: aPTT:24.2 second, INR: 1.21 Blood and urine cultures were negative. The serology of HBV, HCV, HIV, EBV, CMV, Mycoplasma pneumonia, and respiratory viral panel was negative. His chest computed tomography showed characteristic ground-glass opacities in both lungs which were confirmed to be compatible with COVID-19 pneumonia by the radiologist. The serial echocardiography, abdomen, and urinary ultrasonography were normal.

He was treated with azithromycin, favipiravir, enoxaparin sodium, dexamethasone and interferon a treatment. During follow-up in the service, he had severe hypotension that responded to \%0.9 serum saline (SF) loading treatment. His echocardiography was normal about concerning coronary vessels and ejection fraction. Because of innate immunity disorder history, interferon-alpha treatment (Interferon alpha-2a, Roferon A) were added with 3 million IU (MIU) dose for 3 times/week. On the 5 th day of interferon treatment, fever was continuing to be 
over $38^{\circ} \mathrm{C}$ and serum transaminase levels were elevated hence we ended treatment. At the same time, inflammatory markers elevated (platelet elevated to $730 \times 109 / \mathrm{L}$, ferritin was elevated to $4194 \mathrm{mg} / \mathrm{L}$ and also IL-6, CRP, d-dimer, LDH, ApTT, INR, PT prolonged). After ending the interferon-alpha treatment, laboratory findings improved. In the following days, cold type autoimmune hemolytic anemia developed. In his laboratory findings; Hb level decreased to $8.2 \mathrm{~g} / \mathrm{dl}$, hemoglobinuria (+++ positive), macroscopic hematuria (erythrocyte $30 \mathrm{p} / \mathrm{HPF}$ ) and direct Coombs test positivity (+++ positive) developed. Cold agglutinin and paroxysmal nocturnal hemoglobinuria tests were negative. As a result of avoiding cold, the patient's laboratory findings were improved. At the same time, erythema nodosum at the dorsal surface of hands developed. Both hematuria and erythema nodosum disappeared spontaneously. All of these findings, then were found compatible with multisystemic inflammatory disease-related to COVID-19 (MIS-C). Next Generation sequencing (NGS) results for innate and interferon immunity are still pending. His COVID-19 lgG/M antibody titer was >10 (maximum of detectable level) one month after his discharge from hospital. Patient's nail findings which were typical of onychomadesis, begun nearly 2 months after the COVID-19 and was learned to start simultaneously. No treatment was given and lesions healed and disappeared as the nail growth in 2 months period.

\section{DISCUSSION}

In this study, we comprehensively reported a patient with MIS-C which complicated with onychomadesis. When we considered the past infectious history of this patient, we thought that there might be a genetic defect underlying his MIS-C. Zhang and et al. (3) Found 13 genes related to immunity to influenza virus in 659 patients who were diagnosed with severe COVID-19 pneumonia. It is also thought that the coexistence of onychomadesis can be explained by the immuno-pathogenesis of COVID-19. Onychomadesis is characterized by the separation of the nail plate from the nail bed and matrix due to temporary growth arrest of the nail bed matrix (4). Onychomadesis can be caused by a wide variety of reasons. It has been associated with infections, high fever, severe systemic diseases, and medications such as anti-tumoral chemotherapeutics, carbamazepine, lithium salts, retinoids (5). Infections that cause onychomadesis, commonly include viral illnesses such as influenza, measles, and handfoot-mouth disease (HFMD) due to coxsackievirus A6 (5). Guillan Barre syndrome, Steven Johnson Syndrome, Kawasaki disease, paronychia, pustular psoriasis, and trauma were reported to cause onychomadesis $(4,6)$.

The pathogenesis of onychomadesis has not been well defined yet. Viral illnesses may directly damage the nail matrix (7).
Systemic diseases may cause inflammation of the matrix, periungual tissues, or digital blood vessels. Chemotherapy agents may temporarily inhibit the mitotic activity in the nail matrix (7). In COVID-19, macro and microvascular thrombosis involving arteries, veins, arterioles, capillaries, and venules in major organs were observed as well as accumulation of inflammatory cells and apoptotic cells within the vascular endothelium of the heart, small bowel, kidneys, and lungs. Diabetes mellitus, hypertension, obesity which are associated with vascular dysfunction have poor prognosis in COVID-19 (8). Activated leukocytes, platelets, NETosis also alters the function of anticoagulants, may trigger the hypercoagulability in COVID-19 (1). The nail bed which is placed beneath the nail, contains nerves, lymph, and blood vessels. Onychomadesis in COVID-19 may be speculated to be caused by metabolic changes due to microvascular thrombosis in blood vessels at the nail bed leading to a temporary arrest in nail matrix activity. According to Scarfi and et al. (5), the mean onset of onychomadesis after the infection was 40 days. According to Li and et al. (9), the mean onset of onychomadesis associated with the HFMD epidemic in China was 2 months. In our patient onychomadesis started after 2 months of COVID-19 diagnosis. In a recently published case report from Turkey, a 47-year-old female patient was reported developing onychomadesis 3 months after COVID-19 infection (10). In another study, 45-yearold man presented with onychomadesis over all his fingernails and toenails. In his history, he had COVID-19 infection 3.5 months earlier (11). In the literature, several studies present the cutaneous manifestations in COVID-19. Erythematous rash, localized or diffuse urticarial, and chickenpox-like lesions are the most common manifestations (12). Apart from other studies in literature, as an unexpected manifestation of COVID-19, onychomadesis makes this case particularly interesting. This reported study will make practitioners aware of COVID-19 and onychomadesis interrelation.

In conclusion, onycomadesis is a rare condition and can be caused by infections. Association with COVID-19 is limited to our knowledge. More data are required for understanding the etiopathogenesis of the nail affection at COVID-19.

\section{REFERENCES}

1. Jayarangaiah A, Kariyanna PT, Chen X, Jayarangaiah A, Kumar A. COVID-19-Associated Coagulopathy: An Exacerbated Immunothrombosis Response. Clin Appl Thromb Hemost Jan-Dec 2020;26:1076029620943293.

2. Loomba RS, Villarreal EG, Flores S. COVID-19 and Hyperinflammatory Syndrome in Children: Kawasaki Disease with Macrophage Activation Syndrome in Disguise?. Cureus 2020;12:e9515.

3. Zhang Q, Bastard P, Liu Z, Le Pen J, Velez MM, Chen J, et al. Inborn errors of type I IFN immunity in patients with life-threatening COVID-19. Science 2020;370:eabd4570. 
4. Hardin J, Haber RM. Onychomadesis: Literature Review. $\mathrm{Br} J$ Dermatol 2015;172:592-6.

5. Scarfi F, Arunachalam M, Galeone M, Difonzo EM. An uncommon onychomadesis in adults. Int J Dermatol 2014;53:1392-4. 5.

6. Chiu HH, Lan CCE, Wu CS, Kuo KC, Chen GS, Wei KC. Onychomadesis Following Hand-Foot and Mouth Disease. Cutis 2016;97:E20-1.

7. Damevska K, Gocev G, Pollozahani N, Nikolovska S, Neloska N. Onychomadesis Following Cutaneous Vasculitis. Acta Dermatovenerol Croat 2017;25:77-9.

8. Becker RC. Covid-19 associated vasculitis and vasculopathy. J Thromb Thrombolysis 2020;50:499-511.
9. Li D, Wu Y, Xing X, Huang J, Mao A, Liu T, et al. Onychomadesis and potential association with HFMD outbreak in a kindergarten in Hubei province, China, 2017. BMC Infect Dis 2019;19:995.

10. Senturk N, Ozdemir H. Onychomadesis following COVID-19 infection: Is there a relationship?. Dermatol Ther 2020;e14309.

11. Alobaida S, Lam JM. Beau lines associated with COVID-19. CMAJ 2020;192:E1040.

12. Jimenez-Cauhe J, Ortega-Quijano D, Prieto-Barrios M, MorenoArrones OM, Fernandez-Nieto D. Reply to "COVID-19 can present with a rash and be mistaken for Dengue": Petechial rash in a patient with COVID-19 infection. J Am Acad Dermatol 2020 2020;83:e141-e142. 